\title{
Learning Styles in Students of Biomedical Engineering in Cartagena de Indias- Colombia
}

\author{
Diofanor Acevedo ${ }^{* 1}$, Benjamin Acevedo ${ }^{\# 2}$, Luis Beltrán-Cotta ${ }^{* 3}$ \\ *Faculty of Engineering, Research Group Innovation, Agricultural and Agro-industrial Development, University \\ of Cartagena Av. El Consulado, St. 30 No. 48-152. Colombia. \\ ${ }^{\#}$ Faculty of Economics, Public Administration, \\ University of Cartagena Av. El Consulado, St. 30 No. 48-152. Colombia. \\ 1'dacevedoc1@unicartagena.edu.co, ${ }^{2}$ bacevedo1107@hotmail.com, ${ }^{3}$ lbeltrancotta@gmail.com
}

\begin{abstract}
The learning styles and pedagogic strategies applied by teachers were determined in this research. Learning styles were identified in 90 students through CHAEA method; to know about pedagogical strategies, a questionnaire was carried out with teachers. The theoretical style was found to predominate, followed by reflective, pragmatic and active style. This type of education is an important source of didactic action, because it allows us to know the behaviours of how students learn.
\end{abstract}

Keywords: CHAEA, higher education, pedagogy, strategies

\section{INTRODUCTION}

Learning is a process through which people acquire new knowledge and upon which many factors such as individual and collective experiences, information and motivation from social, cultural and emotional influences can influence [1]. Likewise, characteristics such as behaviour, personality, values, preferences and experiences contribute to each person's learning on an individual basis [2].

Learning style is the way a person feels and reacts to learning tasks. Learning theories and their impact on current teaching practices help to identify the most useful resources for rearranging guidance and tutoring to encourage students for independent development in learning [1]. Knowing the students' learning styles can help improve learning and teaching in many ways. In addition, teachers can benefit from this knowledge to prepare material for learning activities that are adapted to students' preferred forms of learning, making student learning easier and more attractive. Meanwhile, students who know their learning styles and individual strengths and weaknesses can better understand why learning is sometimes difficult for them and therefore seek to develop their potential to overcome their weaknesses [3].

Honey and Mumford [4] identified four learning styles that may be predominant in individuals: active, reflective, theoretical and pragmatic. Active style people like group discussions and innovative activities. They are also enthusiastic, improvisers, seekers, daring and spontaneous. Reflective style is predominant in people who prefer to gather data and detailed information, often tend to observe and reflect on their conclusions before acting because the reflectors are prudent. They also possess characteristics such as being prudent, conscientious, receptive, analytical and thorough. The theoretical style prevail in the most curious people and always curious to know the explanation of everything. Together with the above they are also methodical, logical, objective, critical and organized. And finally, in pragmatic style people stand out who can discover techniques in their daily learning because pragmatists are curious to discover new strategies and determine if these strategies are efficient and valid. They also possess characteristics such as being experiential, practical, direct, effective and realistic. Therefore, the objective of this research was to determine the learning styles of the students in the Biomedical Engineeringprogram through the implementation of the CHAEA questionnaire and to establish the pedagogical strategies implemented by the teacher, which contribute to enhance academic performance.

\section{A. Application of the CHAEA questionnaire}

\section{Methodology}

The Honey-Alonso Questionnaire on Learning Styles (CHAEA) was applied to 90 students of the Biomedical Engineeringprogram to identify learning styles: active, reflective, theoretical and pragmatic; consists of 80 questions, which is divided into 20 questions for each style, in which the student was asked whether or not they agreed to their consideration. This process made it possible to identify, characterize and classify students according to their learning style.

\section{B. Determination of pedagogical strategies implemented by teachers}

The questionnaire (Table 1) was addressed to 15 teachers and its purpose was to ascertain their perception of the importance of knowing the learning styles for planning pedagogical strategies and also to identify the pedagogical strategies applied by teachers in the institution, which favor learning styles. 
Table 1. Questionnaire for teachers

\begin{tabular}{|l|l|}
\hline 1 & $\begin{array}{l}\text { Do you consider it necessary to plan pedagogical strategies taking into account the } \\
\text { learning styles of your students? Yes__No__Why? }\end{array}$ \\
\hline 2 & What pedagogical strategies do you apply most frequently in the classroom? \\
\hline
\end{tabular}

\section{RESULTS}

The identification of the learning styles of Biomedical Engineeringstudents was achieved by evaluating the questionnaire following the evaluation of 20 possible points for each style. The characterization of students, according to their learning style, is a contribution for teachers to adjust their teaching style, as they often seek to apply a single pedagogical strategy, which is more responsive to their own interests than to the learning needs of students. The CHAEA questionnaire was applied to identify the predominant styles among the students, obtaining that the most predominant style was the theoretical style, followed by reflective, pragmatic and active styles, as shown in Figure 1. This result indicates that the majority of students (theoretical style) present a tendency to be methodical, structured, and logical, focusing on problems in a staggered vertical way, and rejecting the subjective [5]. The results shown here are similar to those reported by Bahamón et al., [6]and Gravini et al., [7] who applied the CHAEA questionnaire to students from different programs at the University of Boyacá (Colombia) and psychology respectively, obtaining that the theoretical style was the predominant one among the studies carried out.

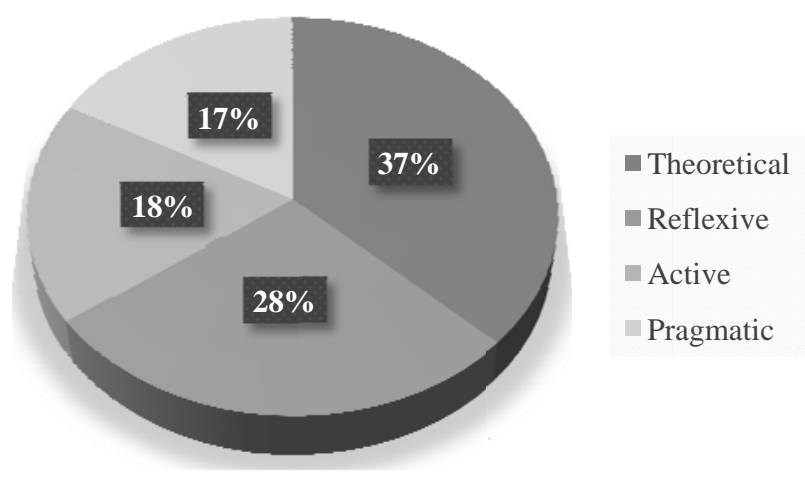

Fig. 1.Predominant learning styles among students

Information on pedagogical strategies used by teachers was obtained through the questionnaire (Table 1) of 15 teachers in the Biomedical Engineeringprogramme. In addition, we inquired about the perception they have of the identification of their students' learning styles and their application in the classroom, the results of the responses can be seen in Figure 2. It can be observed that 90\% of teachers consider it important to plan pedagogical strategies according to the students' learning styles, since in this way better learning is guaranteed, since the interests and needs of the students lead to better learning environments. Ten per cent of teachers responded that they should plan pedagogical strategies according to the pedagogical model of the institution, vision and mission.

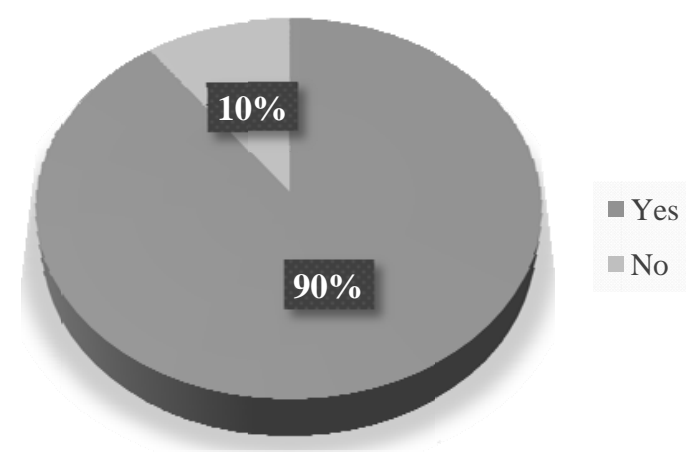

Fig. 2. Planning of pedagogical strategies based on learning styles 
According to the questionnaire applied to teachers (Table 1), when asked about the pedagogical strategies preferred by their students, they affirm that classes are more didactic when dealing with new topics that arouse the curiosity of students, some students assume leadership when they encourage debate in class, supported by arguments, facts and evidence. The students' needs are taken into account, for this reason they are allowed to select their favorite didactic material and resources, teamwork and fieldwork are stimulated, besides the use of graphics, videos and other playful activities to create learning environments, these and other strategies applied by teachers can be seen in Figure 3 .

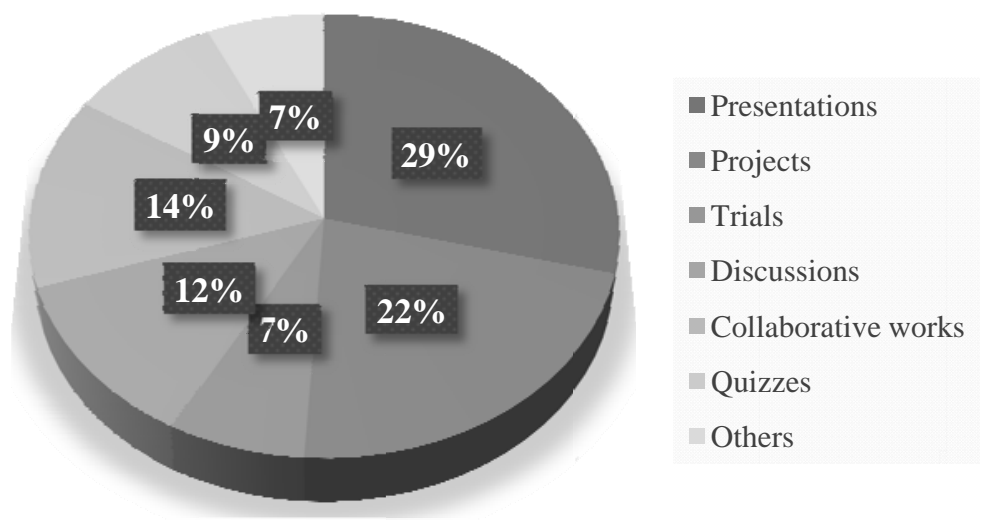

Fig. 3.Pedagogical strategies applied by teachers in the classroom

The application of various strategies is important because teachers use them to improve student learning as indicated by different authors [8].

\section{CONCLuSIONS}

In conclusion, research on learning styles is an important source of didactic action, because it allows us to know the behaviours of how students learn. Among the students of Biomedical Engineering, the theoretical learning style predominates, followed in its order of reflexive, pragmatic and active learning. Regarding pedagogical strategies, it was found that students participate in all the activities proposed by the teacher, but they participate more enthusiastically and have better results with those that are in line with their style.

\section{REFERENCES}

[1] M.Angenetti, V.Polzonetti, and G.Pulcini, "Learning styles as a tool to improve both guidance and tutoring actions,"conference held at the V international conference new perspectives in science education, Florencia, Italia, 2016.

[2] A. Czepula, W.Bottacin, E.Hipólito, D.Baptista, R.Pontarolo, and C.Correr, "Predominant learning styles among pharmacy students at the Federal University of Paraná, Brazil,”Pharmacy practice, Vol.14, no. 1, pp 650, 2016.

[3] P. Alves, L. Miranda, C. Morais and E.Alves,"Proposal of a LearningStylesIdentificationToolforSakai Virtual LearningEnvironment,”Computerscience and engineering, SpecialIssue, 47-54, 2012.

[4] P. Honey and A. Mumford,“Using Our Learning Styles,” Berkshire, U.K., Peter Honey, 1986.

[5] P. Said, M. Díaz, J. Chiapello and M. Espíndola,“Estilos de aprendizaje de estudiantes que cursan la primera asignatura de la carrera de medicina en el nordeste argentino,” Revista Estilos de aprendizaje, Vol. 6, no. 6, pp. 1-18, 2010.

[6] M. Bahamón, M. Vianchá, L. Alarcón and C. Bohórquez, "Estilos y estrategias de aprendizaje relacionados con el logro académico en estudiantes universitarios,’Pensamiento psicológico, Vol.11, no. 1, pp. 115-129, 2013.

[7] M. Gravini, E. Cabrera, V. Avila and I. Vargas, "Estrategias de enseñanza en docentes y estilos de aprendizaje en estudiantes del programa de psicología de la universidad simón bolívar, Barranquilla,”Revista Estilos de aprendizaje, Vol. 3, no. 2, pp. 124-139, 2009.

[8] S. Acosta and A. Boscán,"Estrategias de enseñanza para promover el aprendizaje significativo de la biología en la Escuela de Educación, Universidad del Zulia,”Multiciencias, Vol. 14, no. 1, pp. 67-73, 2014. 